\title{
BUSINESS ANALYSIS BASED ON TRACEABILITY FRAMEWORK ON SUGAR SUPPLY CHAIN
}

\section{ANALISIS BISNIS BERDASARKAN KERANGKA KETELUSURAN PADA RANTAI PASOK GULA}

\author{
Ratna Ekawati $^{1,2)^{*}}$, Yandra Arkeman ${ }^{3)}$, Suprihatin ${ }^{3)}$, Titi Candra Sunarti ${ }^{3)}$ \\ ${ }^{1)}$ Postgraduate of Agroindustrial Technology, Faculty of Agricultural Engineering and Technology, \\ IPB University, Bogor 16680, Bogor, Indonesia \\ ${ }^{2)}$ Industrial Engineering Department, Faculty of Engineering, Sultan Ageng Tirtayasa University \\ Jenderal Soedirman Street Km 03, Cilegon 42435, Banten, Indonesia \\ E-mail: ratna.ti@untirta.ac.id \\ ${ }^{2)}$ Department of Agroindustrial Technology, Faculty of Agricultural Engineering and Technology, \\ IPB University \\ Makalah: Diterima 16 Juni 2020; Diperbaiki 10 April 2021; Disetujui 20 Mei 2021
}

\begin{abstract}
ABSTRAK
Kompleksitas rantai pasok menyebabkan pula keputusan yang komplek untuk masalah yang harus ditangani walaupun sangatlah sulit akan tetapi sangat membutuhkan respon yang cepat dan akurat. Agroindustri gula tebu melakukan proses bisnis yang dimulai dari pemanenan, pengolahan tebu menjadi gula yang selanjutnya didistribusikan ke konsumen melalui distributor atau ke retailer hingga ke konsumen langsung. Permasalahan yang terjadi pada distribusi aliran informasi data pada rantai pasok agroindustry gula adalah adanya gap jumlah presisi stok gula yang ada di antar departemen pemerintah,begitu pula yang terjadi antara kualitas gula nasional seperti raw sugar, gula kristal putih dan gula rafinasi Walaupun proses dari hulu perkebunan hingga pabrik giling tebu sama akan tetapi jumlah produksi dan konsumsi yang ada di kementerian akan berbeda. Oleh karena itu akan diidentifikasi berdasarkan proses bisnis yang terjadi dari mulai tebu ditebang pengangkutan proses giling penyimpanan penjualan hingga pembeli memdistribusikan kepada konsumen. Pendekatan yang digunakan menggunakan pendekatan berorientasi temuan pada referensi supply chain management, diagnosis awal untuk melengkapi investigasi literatur sesuai dengan ecosystem yang terjadi pada kondisi real. Identifikasi permasalahan yang terjadi akan dianalisa berdasarkan gambaran kondisi awal rantai pasok, analisa kebutuhan berdasarkan diagram input-output, diagram use case hingga framework ketelusuran rantai pasok agroindustry gula. sistem penelusuran yang terintegrasi diharapkan akan dapat meningkatkan kontrol proses dan mendeteksi sebab dan akibat ketika suatu produk gagal memenuhi standar dalam aliran informasi sepanjang rantai pasok mulai dari hulu hingga hilir end konsumen. framework traceability yang diusulkan pada proses bisnis agroindustry gula diawali dengan distribusi transaksi dokumen perjalanan produk dari hulu kehilir khusus untuk nilai informasi kualitas dan kuantitas sehingga pemain yang terlibat dalam rantai pasok dalam memantau record data.
\end{abstract}

Kata kunci : agroindustry gula, framework ketelusuran, pencatatan data, rantai pasok

\section{ABSTRACT}

The complexity of the supply chain also causes complex decisions for problems that must be handled even though it is very difficult but requires a fast and accurate response. Sugar cane agroindustry carries out business processes starting from harvesting, processing sugar cane into sugar which is then distributed to consumers through distributors or retailers to direct consumers. The problem that occurs in the distribution of data information flow in the sugar agroindustry supply chain is that there is a gap in the number of precision sugar stocks that exist between government departments, as well as what happens between the quality of national sugar such as raw sugar, white crystal sugar, and refined sugar. Until the sugar cane mills are the same, the amount of production and consumption in the ministry will be different. Therefore, it was identified based on the business processes of cutting sugar cane, transportation, milling, storage, and sales to buyers and distributing it to consumers. The approach used were a finding-oriented approach to supply chain management references and initial diagnosis to complete the literature investigation following the ecosystem in real conditions. Identification of problems that occur was analyzed based on the description of the initial condition of the supply chain, needs analysis based on input-output diagrams, and use case diagrams to the sugar traceability framework. The integrated tracking system was expected to improve process control and to detect cause and effect when a product fails to meet standards in the flow of information along the supply chain from upstream to downstream end consumers. The traceability framework proposed in the sugar agroindustry business process begins with distributing product travel document transactions from upstream to downstream, specifically for the value of quality and quantity information so that players are involved in the supply chain data records.

Keyword: record, sugar agroindustry, supply chain, traceability framework 


\section{INTRODUCTION}

Supply chain conditions require continuous participation and cooperation to quickly respond to market and consumer demands (Chi et al., 2020). Sharing information with stakeholders within the supply chain can increase the benefits of distributing data transactions. Improved process innovation with optimized supply chain performance based on information technology connectivity technology (Hsin Chang et al., 2019). Different decisions in each supply chain process are not considered independent because they will affect profitability (Lejars $e t$ al., 2008). Information technology application in supply chain systems helps improve the managerial flow of products or goods, money, and information. Effective IT implementation is expected to help increase overall profits and bring transparency to the sugar supply chain (Kumar et al., 2015). Demanddriven supply chains from stakeholders in different business processes use the operating reference principle (Verdouw et al., 2011).

A value-driven supply chain coupled with a company's strategic priorities result from the company's deliberate management actions and strategic investments to acquire, develop, and configure appropriate resources, processes, and metrics (Melnyk et al., 2014). Identification in the supply chain is distinguished based on two executive actions: structuring resources and utilizing business processes carried out by the actors involved (Zhu et al., 2020). Over the past few years, the production and demand for sugar products have conflicted. The needs of the community increase with the increase in population while the national sugar production decreases, so it must be assisted by the export of raw sugar to be processed into white crystal sugar and can be consumed directly by the community on the table. Several problems in the sugar supply chain studied were optimizing transportation costs and utilizing sugarcane loading stations based on sugarcane supply and harvest schedules using Fuzzy c-means (FCM) (Pathumnakul et al., 2012). Currently, the sugar production produced from sugar cane is around $80 \%$, while the rest is from other commodities such as sugar palm and beetroot (Ruggeri and Corsi 2019).

It is driven by consumer awareness of the number of precision products in the supply chain and quality throughout the production process to the distribution of sugar products (Yunitasari, 2019). Transparency of interests between stakeholders both vertically and horizontally can trace problems along the supply chain (Liu, 2018). The observable components of product flow, information flow, and financial flow aim to monitor and control the volume, quantity, and quality. Involvement internal and external players in recording transaction data in the supply chain to improve effective and efficient performance (Nicolae et al., 2017).
Traceability is very important in this pandemic. Meanwhile, in everyday life, people care about the food they buy by looking at the food's conditions or ingredients. For sugar products, what is being investigated is quality, whether the product consumed comes from the farmers' original sugar cane or raw sugar from sugar cane. However, the procurement is through imports and then auctioned off by other participants to find which factory will process it or mix the processing at the right time. Mill arrived. Traceability will increase transparency in the series of stages of food product production. Transparency can increase consumer confidence regarding the information carried by-products from upstream to downstream. Traceability is very influential on the sustainability of the supply chain so that integrated and coordinated elements can continue to provide value to the stakeholders involved directly or indirectly.

The existence of transparency can increase consumer confidence in the safety of food products because consumers can access clear information among product supply chain actors regarding the production process and control of food safety. (Shafii and Khadijah, 2012). Therefore, traceability is a continuous management activity in the supply chain that can meet stakeholder demands for transparency in its procedures. Traceability is an essential component of today's supply chains in identifying and monitoring processes along the agro-industrial supply chain. Increasing the flow of information distribution from upstream to downstream can strengthen and improve the business process of the sugar agroindustry in the future.

\section{RESEARCH AND METHODS}

This study will discuss the business processes in the JT sugar supply chain from post-harvest to product to the market and consumers. The proposed method is a framework design based on business processes that are traced by knowing the cause of the problem based on the $\mathrm{WH}$ question.

The initial approach was based on finding orientation to supply chain management references. SCM was analyzed and documented through direct meetings and discussions with players in the sugar supply chain at the TJ factory in the JB Indonesia area (Simon et al., 2014). The steps to identify the sugar supply chain integrase is by reference score (Cooper et al., 1997)

Supply chain conditions require continuous participation and cooperation to quickly respond to market and consumer demands (Chi et al., 2020).

The description above explains that this research is limited to discussing business processes in the sugar supply chain, which are influenced by the network structure from upstream to downstream with its resources from post-harvest, production processes, 
logistics in warehouses, and sales to markets, and consumers.

In this study, referring to Figure 1, the framework methodology described is proposed identifying supply chains based on the mechanism for questioning the distribution of information flow problems between stakeholders through a traceability framework. Traceability in the agro-industrial supply chain system is expected to ensure food safety and quality during this pandemic. So that customer satisfaction, the level of productivity of business processes along the chain can be optimized and improve information connectivity in the supply chain and strengthen logistics processes and food supply chain management in a comprehensive and integrated manner. The company's current condition is centralized data storage, making it difficult for coordination and integration between stakeholders to ensure product quality, speed, and origin. So we need a decentralized system where the availability of information transparently, from upstream farmers to consumers or markets, can feel satisfaction in consuming sugar with the right quality and quantity. after sugar cane is harvested and is delivered to the processing factory with a random truck arrival pattern and first-in, first-out (FIFO) queuing discipline. After that, the sugar cane will be checked physically and non-physically to be processed according to the mill's milling capacity. The waiting time for processing does not exceed 24 hours and follows the sugarcane production process into sugar. In 2020 the JT factory also had raw sugar, which is processed before the sugar cane around the factory matures. Because it is processed with the same equipment, there is a possibility that the sugar cane milling process is mixed with raw sugar. After being packaged sugar, it is differentiated based on bulk sugar and retail sugar. The product will send to the buyer based on the buyer's order made at the sales division. The purchased bulk sugar reaches the buyer and is said to be following the desired quantity and quality. The buyer can sell it to the final consumer by not specifying where the bulk sugar comes from and adding packaging according to the seller's wishes, according to the reference in Figure 2.

\section{RESULT AND DISCUSSION}

Constraints the sugar supply chain starts from various sugarcane farmers from different locations

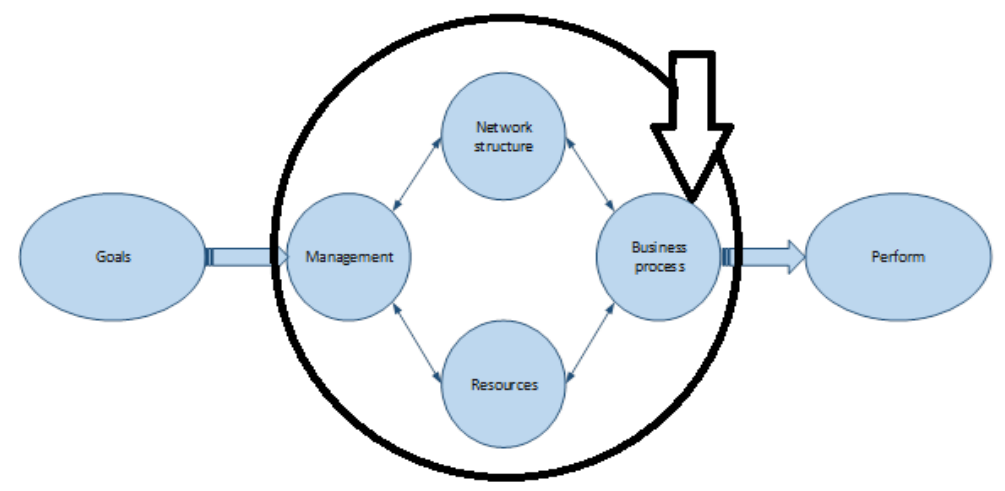

Figure 1. Framework methodology

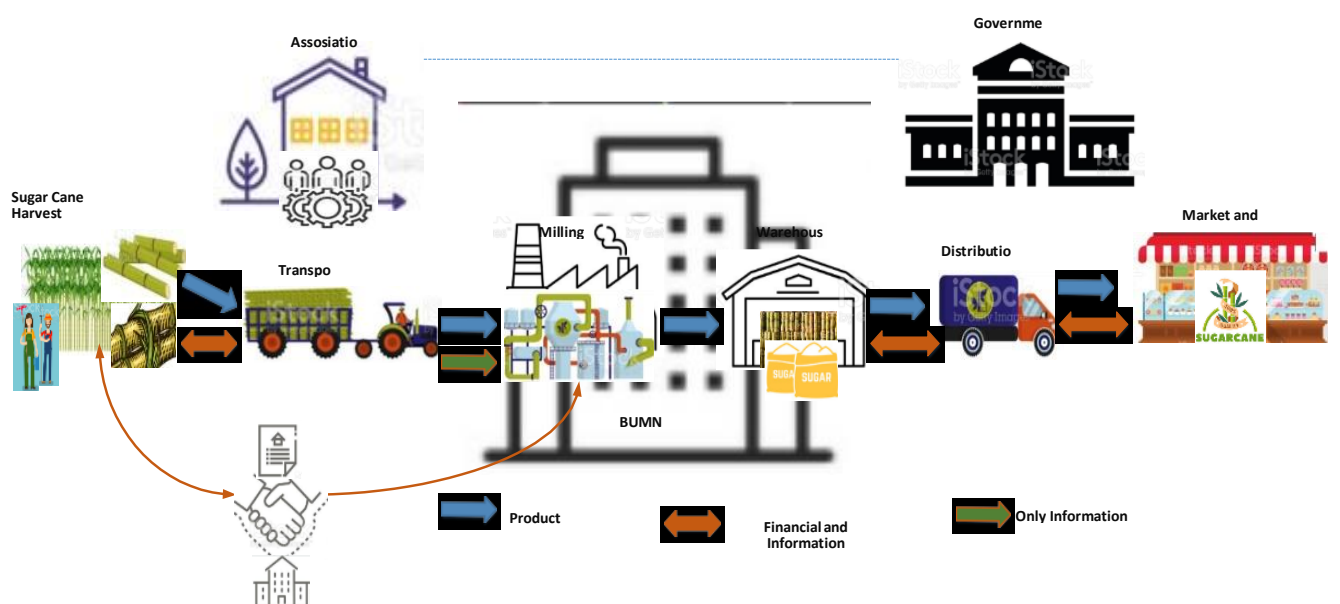

Figure 2. Real condition sugar supply chain 
The product's value that consumers want is the quality and quantity of sugar consumed by the community. It concerns the availability and quality composition that ensures the health of consumers. The components needed in identifying the needs analysis are described in the input-output diagram, including stakeholders, objectives, threats, resources, and controls. Can refer to the input-output diagram based on Figure 3.

The components mentioned above have different needs according to their respective objectives and influence the existing system. The traceability framework is designed to increase business value in the sugar supply chain so that users can control and monitor data so that it is obtained from a single data source. It can minimize the diversity of data circulating today with limited resources. Threats against falsification of transaction data by citing sources from factory $\mathrm{x}$ in the transaction can improve factory performance and increase public confidence in national sugar products. The sugar company's use case interactions can be referred to base on Figure 4.

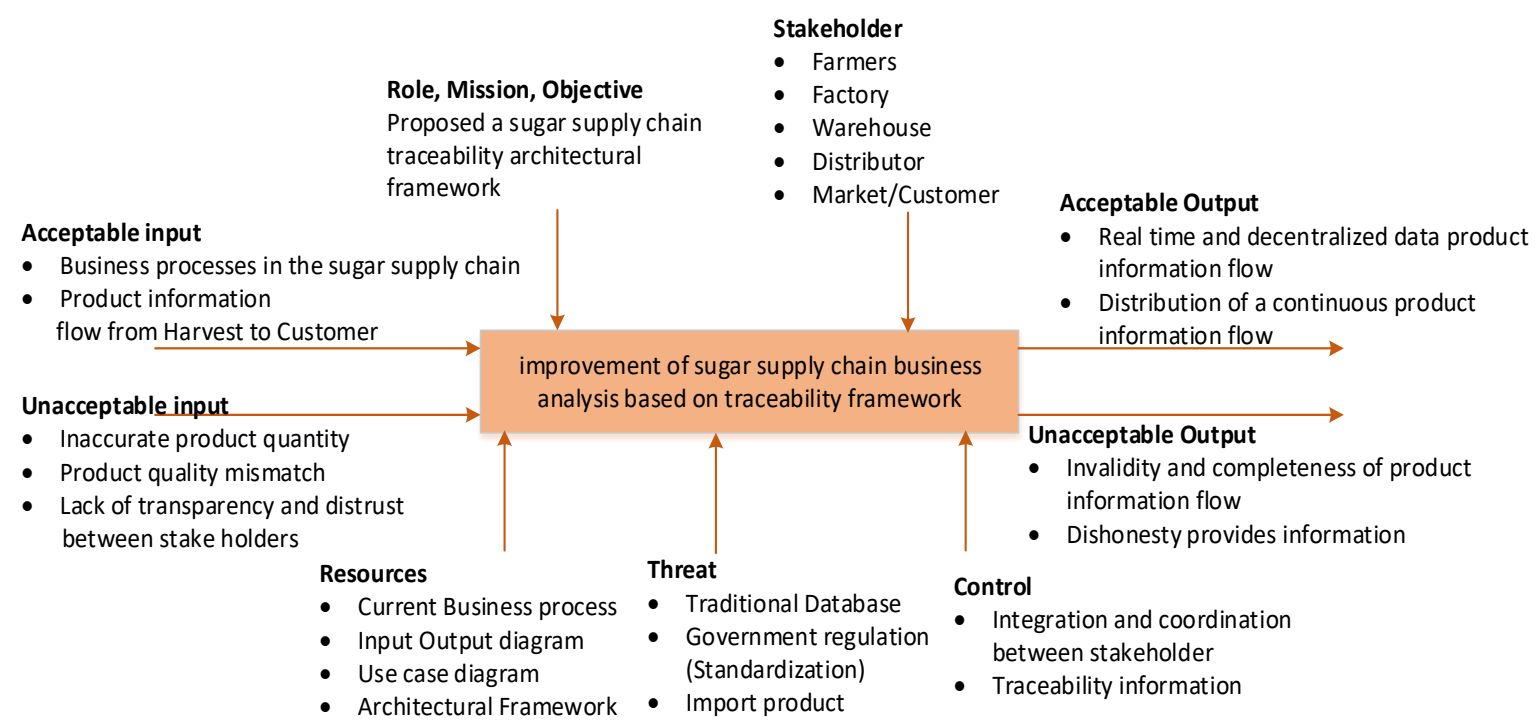

Figure 3. Input-Output diagram

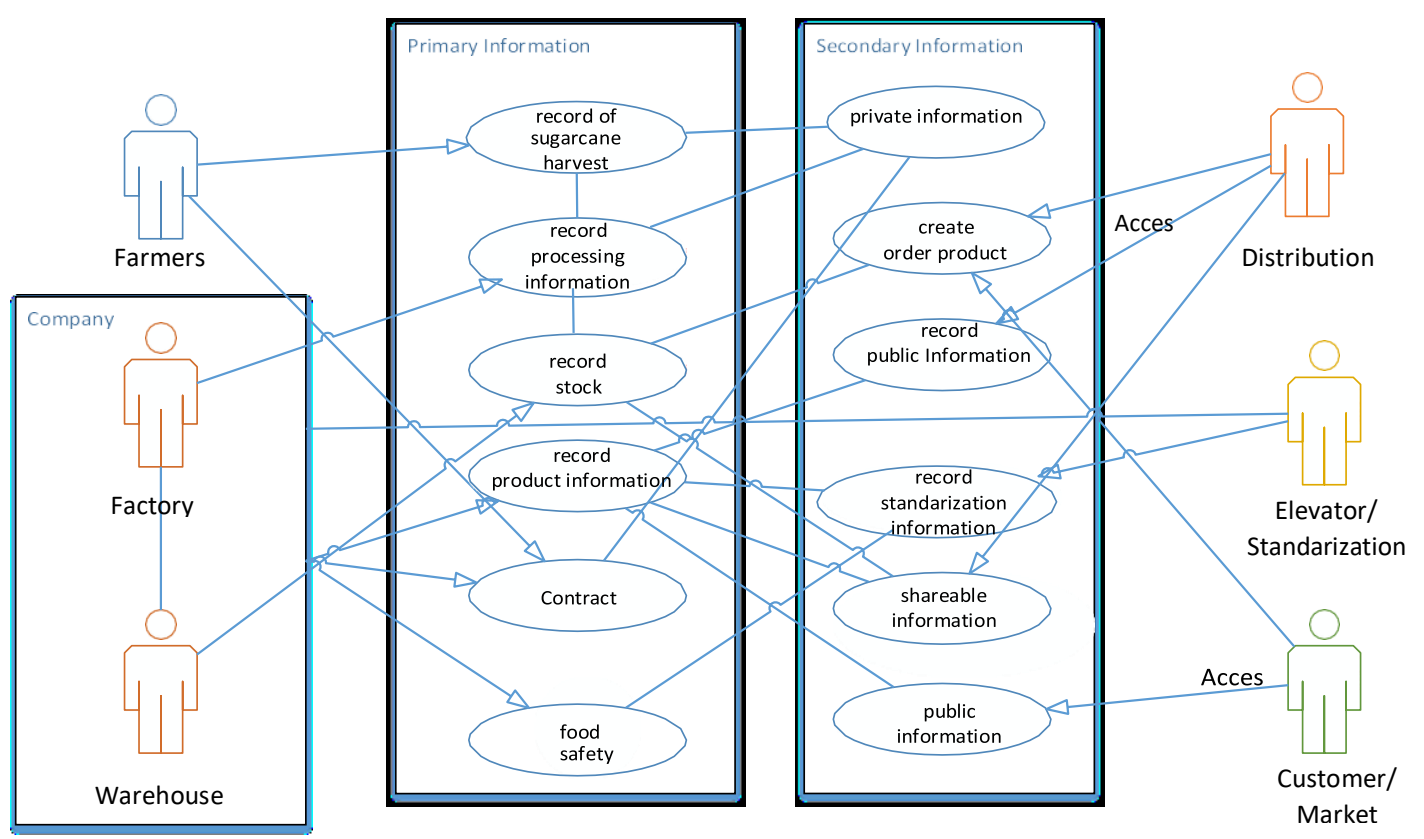

Figure 4. Usecase intecractions sugar company 
The picture above is a use case diagram illustrating complex and integrated interactions in the sugar company environment (Bezuidenhout et al., 2012). on the supply chain process of sugar agroindustry between the leading actor and the ecosystem boundary in explaining the distributed primary and secondary Information (Kostin et al., 2011) (Kostin et al., 2012; Lamsal et al., 2013). Primary information consists of all available information, while secondary information is processed information generated from primary information. The use case is a picture of what the actors in this supply chain do to quickly understand the system and know the needs of its users (Kumar et al., 2017).

The information obtained or accessed and the accuracy and suitability of the value of the distribution of transaction data information. Such data on the quality and quantity of sugar products produced are often discrepancies and discrepancies in the sugar supply chain (for example, there is a discrepancy between the data from the production department at the processing plant and the data at the company center). It is due to incorrect input data, loss of input paper, incorrect input time, carelessness or operators who input differently, and difficulty accessing data information. The primary characteristics of the sugar industry, unstable supply and demand, poor actual data specifications. Due to the lack of coordination and integrity of a centralized information database system.

The analysis coordinated in this study contributes to understanding complex systems in describing situational conditions (Yunitasari, 2019). A sound traceability system can help answer complaints or claims quickly, effectively, and efficiently. Not only the answer but the traceability system can be used as a corrective action in ensuring product quality and quantity so that continuous improvement in integrated business processes between players in the inbound and outbound supply chain is possible. Which aims to increase confidence in national products, and consumers who consume sugar products feel safe for their health. As an example that will be explored, the quality of sugar products following consumer desires is one of the company's goals in satisfying consumers. The quality control process minimizes claims/complaints against products sent to the market/end customers. For sugar products that are batch production, chain length can provide a high potential for distrust problems due to discrepancies in information, data, and product quality that impact consumer dissatisfaction. A traceability framework design for sugar supply chain business can be referred to based on Figure 5.

The company's infrastructure from upstream to downstream distributes value across supply chain networks. There can obtain supply chain performance from value chain activities such as inbound logistics, operations, outbound logistics, marketing and sales, and customer services (Srichanthamit and Tippayawong, 2019). As an example in this research, it is for inbound logistics activities where the value distributed can be qualitative, such as quality, starting from sugar cane sent to mills to turning into sugar products. The quantitative assessment step describes the amount of sugar cane harvested by farmers and then milled by removing the materials carried during cutting and transporting. When the sugar product is produced, it is by SNI standards. New buyers as factory partners are satisfied with the sugar products delivered, thus minimizing product returns.

System design in traceability finding gaps or problems at the supply chain stage, as illustrated in the previous figure. Thus, the part or division of the company involved has the opportunity to collect accurate data about the conditions experienced by their products when leaving the garden, production processes, logistics, sales until they are sent to consumers. It can increase its competitiveness by using the flexibility of accurate and precise technology in recording transactions, records that support supply chain traceability (Accorsi et al., 2016). Data access Traceability at each stage of the supply chain can be informed based on closed supply chain loops. By increasing the visibility of transaction flow data records between players in the supply chain

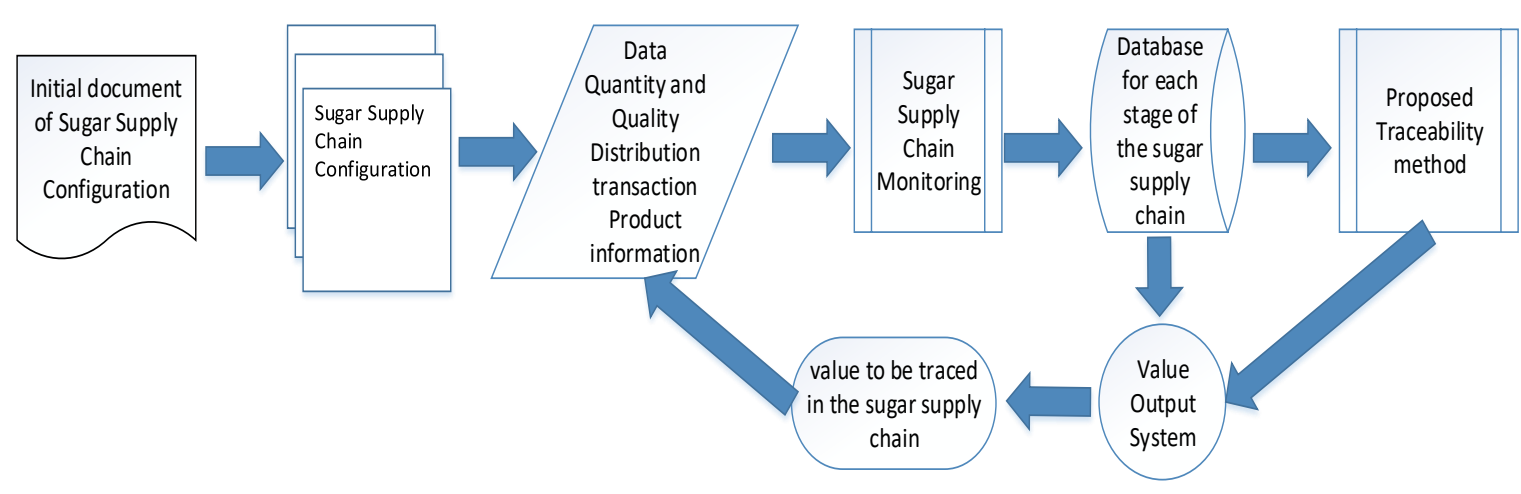

Figure 5. Traceability framework design for sugar supply chain business 
Current market conditions indicate that technological innovation is primarily for coordination and integrity among supply chain actors. During a pandemic like today, digitalization of information is very much needed because we don't need to come to the factory to see a summary report of factory performance. The center can directly pull data by proposing reliable, transparent, eternal technology and traceability capabilities.

Based on the proposed technology, troubleshooting problems, inaccuracies in the number of products, and processing processes, the flow of information can change centralized data to decentralized data to prevent spam, hackers, and falsification of transaction data in the national sugar supply chain. (Hsin Chang et al., 2019). Traceability the value that is carried is qualitative for quality such as sugar standardization and consumer visualization of products that have been purchased and quantitative for the number of batch values between players in the company and precision between other stakeholders in real-time (Hao et al..2020, Surasak et al. 2019).

\section{CONCLUSION AND RECOMMENDATION}

The conclusion obtained is the framework of the agro-sugar business process, especially the distribution of data transactions. So that by tracing the problems that occur, can solve the problem immediately. Supply chain actors can monitor and control transaction data without worrying about actual data. Availability of data in one data source, so that the accuracy and speed of stakeholders in viewing and pulling data to analyze according to their individual needs. Although the data is stored in a simple database, the proposed method for traceability will add value to all players in the supply chain involved optimally. The database will be proposed changes from centralization to decentralization with a good level of trust guaranteed data security because of transparency and data conservation, which can be accounted for because the data that has been inputted cannot be changed again.

Based on further research, business processes for system traceability can be completed with decentralized applications based on blockchain smart contracts. All data is inputted via DApps, code writing solidity program, and factory data. That may publish are stored on the blockchain, so if there is an external need for data, it is easy to withdraw it by creating a wallet that each factory verifies.

\section{ACKNOWLEDGEMENT}

This research received financial support from BUDI DN LPDP. I want to thank Ipb University and Sultan Ageng Tirtayasa University.

\section{REFERENCES}

Accorsi R, Ferrari E, Gamberi M, Manzini R, Regattieri A. 2016. A Closed-Loop Traceability System to Improve Logistics Decisions in Food Supply Chains: A Case Study on Dairy Products. Advances in Food Traceability Techniques and Technologies: Improving Quality Throughout the Food Chain:337-351 doi: 10.1016/B978-0-08100310-7.00018-1 .Elsevier Ltd.

Bezuidenhout CN, Bodhanya S, and Brenchley L. 2012. An analysis of collaboration in a sugarcane production and processing supply chain. British Food Journal. 114(6):880-895. doi:10.1108/00070701211234390.

Chi M, Huang R, and George JF. 2020. Collaboration in the demand-driven supply chain: Based on a perspective of governance and IT-business strategic alignment. International Journal Information Management. 52 :1-13. doi:10.1016/j.ijinfomgt.2019.102062.

Cooper MC, Lambert DM, and Pagh JD. 1997. Supply Chain Management: More Than a New Name for Logistics. The International Journal of Logistics Management. 8(1):1-14. doi:10.1108/09574099710805556.

Hao Z, Mao D, Zhang B, Zuo M, Zhao Z. 2020. A novel visual analysis method of food safety risk traceability based on blockchain. International Journal Environmental Research and Public Health. 17(7):1-18. doi:10.3390/ijerph17072300.

Hsin Chang H, Hong Wong K, Sheng Chiu W. 2019. The effects of business systems leveraging on supply chain performance: Process innovation and uncertainty as moderators. Information and Management. 56(6):103140. doi:10.1016/j.im.2019.01.002.

Kostin AM, Guillén-Gosálbez G, Mele FD, Bagajewicz MJ, Jiménez L. 2011. A novel rolling horizon strategy for the strategic planning of supply chains. Application to the sugar cane industry of Argentina. Computers and Chemical Engineering. 35(11):2540 2563.

doi:10.1016/j.compchemeng.2011.04.006.

Kostin AM, Guillén-Gosálbez G, Mele FD, Bagajewicz MJ, Jiménez L. 2012. Design and planning of infrastructures for bioethanol and sugar production under demand uncertainty. Chemical Engineering Research and Design. 90(3):359-376. doi:10.1016/j.cherd.2011.07.013

Kumar R, Agrawal R, and Sharma V. 2015. IT enablement in the sugar supply chain: An approach for farmers. International Journal Business Performance and Supply Chain 
Modelling.

$7(4): 360-381$ doi:10.1504/IJBPSCM.2015.073770.

Kumar V, Hallqvist C, and Ekwall D. 2017. Developing a framework for traceability implementation in the textile supply chain. Systems.

$5(2): 33$ doi: $10.3390 /$ systems 5020033 .

Lamsal K, Jones PC, and Thomas BW. 2013. Sugarcane harvest logistics in Brazil. Iowa Research Online .51(2):771-789. https://doi.org/10.17077/3r66eunf\%0ACopyright.

Lejars C, Gal PLe, and Auzoux S. 2008. A decision support approach for cane supply management within a sugar mill area. Computers and Electronics in Agriculture. 60:239-249. doi:10.1016/j.compag.2007.08.008.

Liu Y. 2018. traceability management for the food safety along with the supply chain collaboration of agricultural products. Agriculture, Forestry and Fisheries. 7(2):5864. doi:10.11648/j.aff.20180702.13.

Melnyk SA, Narasimhan R, and Decampos H. 2014. Supply chain design: issues, challenges, frameworks, and solutions. Journal production Research. 52(7):1887-1896. doi:10.1080/00207543.2013.787175.

Nicolae CG, Moga LM, Bahaciu GV, Marin MP. 2017. Traceability System Structure Design for Fish and Fish Products Based on Supply Chain Actors Needs. Scientific Papers-Series D-Animal Science. 60,September:353-358.

Pathumnakul S, Sanmuang C, Eua-Anant N, Piewthongngam K. 2012. Locating sugar cane loading stations under variations in cane supply. Asia-Pacific Journal Operational Research. 29(5):1-17. doi:10.1142/S0217595912500285.

Ruggeri $G$ and Corsi S. 2019. An analysis of the Fairtrade cane sugar small producer organizations network. Journal Cleaner Production. 240:1-13. doi:10.1016/j.jclepro.2019.118191.

Simon AT, Satolo EG, Scheidl HA, Sério LC Di. 2014. Business process in supply chain integration in sugar and ethanol industry. Business Process Management Journal. 20(2):272-289. doi:10.1108/BPMJ-04-20130043.

Srichanthamit T and Tippayawong KY. 2019. A Framework for Measuring Value Chain Performance in the Sugar Industry. Springer Nat Singapore Pte Ltd.,: 369-379.doi: 10.1007/978-981-13-1059-1

Surasak T, Wattanavichean N, Preuksakarn C, Huang SCH. 2019. Thai agriculture products traceability system using blockchain and Internet of Things. International Journal Advanced Computer Science and Applications. 10(9):578-583. doi:10.14569/ijacsa.2019.0100976.

Verdouw CN, Beulens AJM, Trienekens JH, Van Der Vorst JGAJ. 2011. A framework for modelling business processes in demand-driven supply chains. Production Planning and Control. 22(4):365-388. doi:10.1080/09537287.2010.486384.

Yunitasari D. 2019. Achieving self-sufficiency through sugar supply and demand policies (Dynamics system approach). International Journal of Scientific \& Technology Research. 8(3):34-40.Issn: 22778616

Zhu Z, Zhao J, and Bush AA. 2020. The effects of ebusiness processes in supply chain operations: Process component and value creation mechanisms. International Journal Information Management.273-285. doi:10.1016/j.ijinfomgt.2019.07.001 